\title{
Do Online Classes help EFL Learners Improve their English Language skills? A Qualitative Study at a Saudi University
}

\author{
Mohammed Madi Albogami \\ Department of Arts and Education, \\ Riyadh Community College \\ King Saud University, Riyadh, Saudi Arabia \\ Email: mmalboagmi@ksu.edu.sa
}

Received: $8 / 26 / 2021$

Accepted:12/6/2021

Published: $1 / 24 / 2022$

\begin{abstract}
The unprecedented time of COVID-19 has called schools and educators worldwide to think of transferring education from face-to-face based to become more digital oriented. This transformation has pros and cons. Scholars in the field are questioning investigating the challenges that online learning entails; however, one of the issues still not fully investigated in the literature is how effective online learning on improving the EFL learners' language skills. Thus, the purpose of this study is to explore the perspectives of EFL learners toward how effective online learning on improving their English language skills. The participants involved were three students from the Community College at King Saud University. Semi-structured interviews were used to gather the data in the study. The results from the qualitative data showed that the participants reported some flaws associated with online learning. However, they preferred such learning methodology to face-to-face instruction as they feel more comfortable when attending their classes from home, saving their time and costs. Moreover, the findings showed that online learning helps the learners develop all their language skills, makes them more concentrated, confident, and encourages them to become autonomous learners. The results also suggested that online learning helps EFL learners develop their online learning skills. The outcomes of this research build on the current literature on using online learning in EFL classrooms during the COVID-19 pandemic.
\end{abstract}

Keywords: challenges, COVID-19, face-to-face, English language skills, online learning, Saudi EFL students

Cite as: Albogami, M.M. (2022). Do Online Classes help EFL Learners Improve their English Language skills? A Qualitative Study at a Saudi University . Arab World English Journal (AWEJ) $2^{\text {nd }}$ Special Issue on Covid 19 Challenges (2) 281-289.

DOI: https://dx.doi.org/10.24093/awej/covid2.18 


\section{Introduction}

Since the outbreak of the COVID-19 pandemic back in March 2020, most of the countries adopted and promoted the use of technology in their educational systems to control the spread of the COVID-19 and protect their citizens. Saudi Arabia was one of the first countries that lock down its schools and higher education institutions since the outbreak of the pandemic to confront the quiet spread of the virus. Therefore, the Saudi government promoted the use of online learning in its educational system to make sure that its learners are up to date with their learning in secure environments. Thus, it adapted learning platforms such as Zoom, Madrassati (a platform designed by the Saudi Ministry of Education), Blackboard LMS, and Microsoft Teams to serve this purpose. However, when teaching English language skills to university learners is concerned, little attention is paid to investigate how practical the online classes are in helping such learners develop their English language learning since most of the literature is exploring the challenges and difficulties associated with online learning in EFL contexts. Thus, exploring how effective online learning on acquiring the English language skills, in particular, is essential for this paper to provide a clear picture of how practical such methodology is in teaching and learning English in EFL contexts; more specifically in the Saudi context. Therefore, the main research question proposed by this paper is:

1- How effective is online learning in improving the Saudi EFL learners' English language skills?

\section{Literature Review}

Teaching English to EFL learners using remote platforms has become a debatable topic among researchers to investigate these days. Remote learning, online learning, or distance learning are common terms used to describe "a set of technology-mediated methods that can be applied to support student learning and include elements of assessment, tutoring, and instruction" (Wheeler, 2012, p.1109). This definition gives a clear picture about the nature of online learning and how it is embedded in teaching and learning settings.

Al-Samiri (2021) noted that there are two main streams of online learning; synchronous and asynchronous. She defined the term synchronous as "teaching occurs live with students and instructors both present online in real-time" ( $\mathrm{p}, 149)$; whereas, asynchronous refers to "the content and instruction are available for the students to access any time via recordings of the lessons or independent online activities" (p.149).

Nowadays, researchers have become more interested in investigating the challenges and benefits of online learning in EFL contexts. Al-Samiri,(2021) for example, reviewed 40 articles published highlighting the challenges and benefits of online teaching of English as a foreign language in the Saudi context during the onset of the COVID-19 pandemic. She concluded that online classes could help shy and struggling learners in the classroom become more active agents; however, online classes are considered a "less-than-optimal learning environment" (p.150), which affects the learners' motivation when they face technical issues. Also, she added that at the time, technology is convenient in saving time and effort as teaching and learning occur remotely from homes, education is interrupted and affected by other factors surrounding the learners such as family members at home distracting them from learning and the learners' anxiety toward online learning might be noticeable (Al-Samiri, 2021). 
Moreover, Al-Samiri highlighted that the digital readiness of both the learners and their teachers is another issue making the best benefits of technology are inaccessible. To remedy this, she suggested that providing the needed technical support and the proper learning input must be maintained. In the same vein, Rahman (2020) conducted a study investigating the perception of EFL learners toward online learning in the Indonesian context and reported that online learning was perceived as less facilitating, and the learners faced technical issues such as internet connectivity during their learning. However, the results of their study showed that online learning contributed to provide the learners with flexibility for their learning, enhance their autonomy and confidence. They finally concluded that learning through F2F (face-to-face) is rather beneficial than providing instruction online.

Similarly, Tanjung and Utomo (2020) conducted a study in the Indonesian context investigating the EFL learners' perception of implementing full-online learning mode in the English classroom. The findings of their study showed that the learners developed both positive and negative views regarding online learning. From the positive side, the learners become familiar with search engines, social media, e-resources, and learning apps; and it promotes autonomous learning. On the other hand, the current learning platforms do not meet the learners' expectations and needs. Thus, the authors suggested the need to do some technical improvements on the platforms to encourage the learners to become more engaged in their learning activities.

As far as the Saudi context is concerned, few studies were conducted to explore the challenges and problems faced by EFL teachers and students and their perception of online learning. Akhter (2020), for example, carried out a study investigating the challenges and problems faced by the EFL university-Saudi students during the COVID-19 pandemic. His study focused only on listening as the author thought it is problematic in EFL contexts due to the limited practice opportunities in such settings. They invited 100 participants to complete their online survey. From their data, the learners experienced a moderate to a high level of difficulty in listening due to limited resources. They concluded that most of the students encountered problems in listening most of the time during the online classes, and sometimes due to physical and other barriers. They also suggested that the teachers need to be educated and trained with adequate information and skills to optimize their online learning activities. However, the other language skills, reading, speaking, and writing are not thoroughly researched in their study, indicating that investigating the impact of online learning on acquiring these skills in this context is essential.

In the same context, more studies were published investigating the impact of online learning on learners' motivation. Ur Rahman (2020) reported from their survey to 50 English instructors across the Kingdom that $68 \%$ of the participants believed that the learners become less motivated when it comes to online learning. Al-Samiri (2021) argues that lack of motivation should not be necessarily matched with online learning as there are other factors that could contribute to causing such phenomena like social isolation, weak internet connectivity, home distraction, and disability to achieve class objectives. Other studies linked demotivation to the mental health issues caused by the COVID-19 pandemic. Alkhamees, Alrashed, Alzunaydi, Almohimeed, and Aljohani (2020) reported from their study that the Saudi people were depressed and suffered from stress disorder due to the COVID-19 pandemic. Similarly, Hasan 
and Bao (2020) highlighted that Saudi college learners suffer from psychological distress due to the pandemic.

From another perspective, there are some issues associated with online learning, such as technical issues and digital readiness. Al-Nofaie (2020), for example, conducted a study on Saudi female learners at Taif university to investigate Blackboard readiness. The study involved surveying 25 female learners majoring in English. The results indicated that the participants lacked digital readiness and technology skills; as well as the learners experienced issues with their internet connectivity and bandwidth. Furthermore, Bin Dahmash (2020) interviewed 12 female university Saudi learners to explore their perspectives towards the benefits and challenges of blended learning during the spread of the COVID-19 pandemic. The results of her study revealed that the learners benefited from blended learning in improving their writing and digital skills; however, the learners encountered some technical problems such as incompatibility of the devices with the Blackboard platform, sound interruption, and intermittent session access. Likewise, Ali and Abdalgane (2020) conducted a study to compare teaching literacy before and after the COVID-19 pandemic and how the learners were evaluated during the pandemic era. They reported that online learning did not interrupt the teaching of literacy to Saudi learners, and, the teachers were able to evaluate the learners using different tools; however, their study revealed some constraints such as weak internet connectivity and lack of technical support available for both the teachers and the students.

From the above studies, it can be clear that much of the attention in the field was paid to investigate the issues and challenges associated with online learning in the EFL contexts. Apart from Akhter's (2020) study, little is known about the impact of online learning on acquiring the other English language skills; reading, writing, and speaking in an EFL context. Thus, this study will attempt to fill this gap using a qualitative inquiry.

\section{Methods}

\subsection{Data Collection}

This study adapted the interpretive case study research since the learners' experiences with online learning in acquiring the English language skills are very paramount to answer the research question proposed by the current research. To collect the data for this study, semistructured interviews used as they are considered the most appropriate method in qualitative research to gain an in-depth understanding of the investigated phenomena (Bryman, 2012). In this study, they provided the participants with the appropriate flexibility to express their thoughts and elaborate on their responses. Also, they allow the researchers to ask the same questions to all the interviewees to obtain much information regarding their research issue (Bryman, 2012). Following Kallio et al.'s (2016) suggestion, the interview guide was developed. The questions were well-formulated, not leading, clearly worded, and open-ended to elicit the responses from the participants. The participants purposefully sampled as the participation was completely voluntary. Thus, the number of participants involved in the study was three.

\section{2 participants}

The participants invited to participate in the study were Saudi male learners who completed and studied an online English course at Riyadh Community College for one semester. Their ages range from 18-20. They studied the English course as a prerequisite for their 
academic programs at the College. The students in this module learn the four English language skills (i.e., reading, writing, listening, and speaking).

\subsection{Procedure and data analysis}

Due to the undergoing COVID-19 restrictions in the country and for the safety of the participants, the interviews were conducted remotely using Zoom App. The interview with every interviewee was in Arabic to elaborate on their thoughts without any difficulty and lasted for about 30 minutes. The participants were initially asked to provide their views on online learning in general and on learning the English language skills in particular. Following the participants' approvals, all the interviews were recorded on a recording device. Credibility and confirmability, of the research method, were achieved in this study by inviting qualitative experts to check the appropriateness of the open-ended questions, their content, clarity, and length to find answers to the research question proposed, as for confirmability, all the transcripts were sent by email to the participants to confirm their utterances and report any concerns regarding their recordings. The data collected was analyzed using the thematic analysis suggested by Braun and Clarke (2006). All the collected data were read and re-read several times. Codes are generated and grouped under sub-themes and themes. For ethical considerations, all the participants were informed about the study, their roles in the research, and assured their anonymity and confidentiality when reporting their data.

\section{Results}

As this study aimed at exploring the effectiveness of online learning on acquiring English language skills, the findings of the current research build on the existing literature regarding the use of online teaching in L2 classrooms. Two main themes emerged from the data of this study: the perception of EFL learners toward online learning in general and its impact on English language learning.

\section{The Perception of Online Learning in L2 Classrooms}

The participants of this study preferred online learning, although they reported some flaws associated with such learning methodology. They believe that it is convenient, makes them less stressed, and saves money, and time. They illustrated:

Ali: "I greatly felt comfortable and saved my money from spending on transportation from, and to the university and what will be given in the lectures can be given online. It is nice."

Badr: "It is good for the students who live outside the region or far from the university and do not have commuting means."

Faisal: "online learning from home is very convenient, and saves our time in avoiding traffic or being late to lectures."

However, the participants of this study believed that online learning carries some disadvantages; internet interruption, weak Wi-Fi signals, technical readiness, technical problems, and sound interruption. The participants articulated:

Ali: "internet interruption problems, it happened with me so many times. Internet interruptions caused me many attendance troubles. Also, there are no demonstrative videos on how to use the 
Arab World English Journal (AWEJ) 2nd Special Issue on Covid 19 Challenges January 2022

Do Online Classes help EFL Learners Improve their English Language skills

Albogami

Blackboard platform to access the courses, unlike the Zoom app, which I found more convenient".

Badr: "Wi-Fi bundles sometimes do not provide the appropriate signal strength, which causes some flaws to learning."

Faisal: "I faced some internet interruption and microphone problems when using Blackboard, but when it comes to the Zoom app, everything worked well. There is a lot of pressure on the Blackboard server, making us wait long periods before joining our classes."

\section{The Impact of Online Learning on English Language Teaching}

The participants of this study revealed that teaching English online is rather beneficial for them. Also, the teachers become more focused and concise when delivering the information to the learners. Moreover, online learning can help the students develop their online learning skills by looking for the meaning of the words instead of being dependent on their teachers. The participants stated:

Ali: "It's one the best experiences I have come across when learning English. The teacher tried to deliver the information clearly and concisely, making it easy for us to understand. That is why it is the easiest term I have ever studied English without having trouble [...], I would go for attending my classes online rather than face to face because it is more convenient for me, and I feel comfortable."

Badr: "I benefited a lot even more than attending English classes at my secondary school. I also developed more skills like using Google translator to translate words for me".

Faisal: "It is perfect. One of the best online courses this term is the English course, frankly speaking. The course is not dense making me feel excited and prepared for its class."

As for the language skills, the study participants advocated that most of their language skills have greatly improved with online learning. They articulated:

Ali: "I am pretty sure I have developed them all [...], at the time the teacher speaks, I start writing down my notes using my mobile. My writing improved a lot because we did a lot of exercises with the teacher about spelling and grammar. I also use social media apps to communicate with my L1 friends in chatting, whether spoken or written. I started to notice my spelling improved. All of the words were correct. I have no problems with my speaking because I speak a lot in English inside the classroom and outside with my friends. For my reading, I read a lot in English, especially stories. I like them so much [..], so I have become a fast reader, and I can guess the meaning of the word easily".

Badr: "The reading and listening skills have developed a lot, and I can understand the meaning of the words and know what to do in the activities."

Faisal: "With studying online, my reading and listening skills developed more, and more because of the listening activities we are doing in the class with the teacher and my frequent participation in the class as well. We are reading too much in the class with the teacher, making me more confident when I read, unlike reading in a face-to-face class, where other classmates like to interfere most of the time to correct or to ask for participation. As for speaking, surely it developed a lot because I always speak English in the class; and for my writing, now I know the 
Arab World English Journal (AWEJ) 2nd Special Issue on Covid 19 Challenges January 2022

Do Online Classes help EFL Learners Improve their English Language skills

Albogami

basics of writing a sentence in English because we took this with the teacher in our online classes".

\section{Discussion}

As this study aimed to investigate the EFL learners' perspectives on how effective online learning is on acquiring English language skills, the findings indicated that online learning is very beneficial in saving time and costs and keeping them punctual with their education. This finding is similar to the one by Bowen et al. (2012), who found from their study when comparing face-to-face teaching to online learning that the outcomes are almost the same, but with online learning, the learners were able to save transportation costs. In this study, studying from home helps the learners attend their classes comfortably from home without thinking of daily traffics and transportation costs. Yulia (2020) advocated that online learning can help learners receive their education without leaving their homes. Thus, someone can argue that online learning contributes to punctual learning without costing the students extra costs as they attend their classes conveniently from home. This can be added to the advantages of online learning mentioned in the literature that saving costs is another positive feature of online learning.

Also, the findings of the current study suggested that the participants face technical and training issues, making them daunted about achieving the best of technology when learning online. These findings are similar to those of Al-Samiri (2021), ur Rahman (2020), Al-Nofaie (2020), Bin Dahmash (2020), and Ali and Abdalgane (2020). As noted by previous studies, these issues can be avoided by adopting other technical alternatives or improve the current teaching platforms. Tanjung and Utomo (2020), for example, remarked that the online platforms need frequent improvements or teachers can consider other alternative platforms such as Zoom. The participants of the current study valued the use of the Zoom app and expressed that it is convenient, and its flaws are minimal. This can indicate that the current BB (Blackboard) platform and its features are complicated for the learners to access and benefit from. Thus, it might be useful to consider some frequent improvements for the BB platform to make it more friendly oriented, and more accessible and promising for the learners to benefit from. Moreover, Akhter (2020) noted that teachers need to be educated and trained with adequate information and skills to optimize their online learning activities. Likewise, the participants of this study suggested that the students need to be educated and trained on how to use learning platforms such as Blackboard to make its benefits accessible for them.

Moreover, the findings indicated that attending online classes is more beneficial for the participants of this study which contradicts with the findings of ur Rahman (2020), who reported that attending English classes F2F (face-to-face) is more beneficial for EFL learners than teaching them online. This finding also matches the results of Tanjung and Utomo (2021), who found that online education can help learners become more autonomous and familiar with search engines and e-resources. It is evident from the qualitative data of this study that online education provides the learners with great opportunities to expand their knowledge to consider and utilize other online recourses available for them to help with their learning. According to these findings, someone can conclude that online learning, regardless of their flaws, is very instrumental to adopt in ELT classrooms as they create an optimal learning environment for both the teachers to become more concise and focused when teaching and for the students to help them use other eresources and learning apps that encourage them to become autonomous learners. This finding 
refutes Al-Samiri's (2021) claim that online learning provides EFL learners with less-thanoptimal learning environments.

Furthermore, the findings suggested that online learning provides the participants of this study with an outstanding possibility to develop their language learning. Merzifonluoglu and Gonulal (2018) mentioned that using technology in teaching EFL offers new opportunities for both the teachers and the learners. In this study, some participants seemed to become more concentrated, motivated, and confident when learning English language. This matches Cutter's (2015) claim that using technology in EFL classrooms increases the learners' motivation. It is also in line with Genc's (2009) statement that using technology while teaching EFL learners helps them develop the four language skills (i.e., listening, reading, speaking, and writing). Thus, it can be concluded that the beneficiary of online learning cannot be underestimated in EFL classrooms regardless of the flaws highlighted in the literature as the participants of the current research found it very useful in developing their language skills, encouraging them to become more confident and motivated.

\section{Conclusion}

This study builds on the current debate on the effectiveness of using online learning in EFL classrooms. It investigated how effective online learning is on acquiring English language. It is evident in this research that online learning is more beneficial for EFL learners regardless of the flaws it contains. In this study, the EFL learners valued online learning to face-to-face instruction as they feel more comfortable while attending their classes remotely from their homes and saving their time, and cutting transportation costs from commuting from and to the university. Moreover, online learning allows the opportunity for the learners to become more concentrated, motivated, confident, and autonomous learners. As for English language skills, it is evident in this study that online learning helps learners develop their both language skills and elearning skills. Further research on blended learning in which EFL instruction is delivered partially online and the rest in person is suggested to understand its impact on acquiring the language for EFL learners.

\section{About the Author:}

Mohammed Madi Albogami is an assistant professor of TESOL at Riyadh Community College at King Saud University, Saudi Arabia. He completed his Doctorate in TESOL at Exeter University, UK. His research interests include effective written feedback, teacher professional development, critical pedagogy, and assessment. ORCID: https://orcid.org/0000-0002-9584$\underline{7962}$

\section{References}

Akhter, T. (2020). Problems and challenges faced by EFL students of Saudi Arabia during the COVID-19 pandemic. Rupkatha Journal on interdisciplinary studies in Humanities, 12(5), 1-7. DOI: 10.21659/rupkatha.v12n5.rioc1s23n5

Ali, R., \& Abdalgane, M. (2020). Teaching English literacy in the time of COVID-19 pandemic in higher education: A case study in Saudi Qassim university. Multicultural Education, 6(5), 204-215. DOI: 10.5281/zenodo.4374526 
Arab World English Journal (AWEJ) 2nd Special Issue on Covid 19 Challenges January 2022

Alkhamees, A., Alrashed, S., Alzunaydi, A., Almohimeed, A., \& Aljohani, M. (2020). The psychological impact of COVID-19 pandemic on the general population of Saudi Arabia. Comprehensive Psychiatry, 102, 1-9. https://doi.org/10.1016/j.comppsych.2020.152192

Al-Nofaie, H. (2020). Saudi university students' perceptions towards virtual education during Covid-19 pandemic: A case study of language learning via Blackboard. Arab World English Journal, 11(3), 4-20. DOI: https://dx.doi.org/10.24093/awej/vol11no3.1

Al-Samiri, R. (2021). English language teaching in Saudi Arabia in response to the COVID-19 pandemic: challenges and positive outcomes. Arab World English Journal, Special Issue on Covid 19 Challenges(1), 147-159. DOI: https://dx.doi.org/10.24093/awej/covid.11

Bin Dahmash, N. (2020). 'I couldn't join the session': benefits and challenges of blended learning amid COVID-19 from EFL students. International Journal of English Linguistics, 10(5), 221-230. DOI:10.5539/ijel.v10n5p221

Bowen, W., Chingos, M., Lack, K., \& Nygren, T. (2012). Interactive learning online at public universities: evidence from randomized trials. Ithaka S+R. (http://www.sr.ithaka.org/)

Braun, V., \& Clarke, V. (2006). Using thematic analysis in psychology. qualitative Research in Psychology, 3(2), 77-101.

Bryman, A. (2012). Social Research Methods (4th ed.). Oxford University Press.

Cutter, M. (2015)."Using Technology with English Language Learners in the Classroom". Education Masters. Paper 313.

Genc, B. (2009). Effect of technology on motivation in EFL classrooms. Turkish Online Journal of Distance Learning-TOJDE, 10(4), 136-158.

Hasan , N., \& Bao, Y. (2020). Impact of "e-Learning crack-up" perception on psychological distress among college students during COVID-19 pandemic: A mediating role of "fear of academic year loss". Children and Youth Services Review, 118, 1-9. DOI: 10.1016/j.childyouth.2020.105355.

Kallio, H., Pietila, A., Johnson, M., \& Kangasniemi, M. (2016). Systematic methodological review: developing a framework for a qualitative semistructured interview guide. Advanced Nursing, 72(12), 2954-2965. DOI: 10.1111/jan.13031.

Merzifonluoglu, A., \& Gonulal, A. (2018). Review of Digital language learning and teaching: Research, theory, and practice. Language Learning \& Technology, 22(1), 65-68. ISBN: 978-1138696815

Rahman, K. (2020). Learning amid crisis: EFL students' perception on online learning during COVID-19 outbreak. ETERNAL, 6(2), 179-194.

Tanjung, F., \& Utomo, A. (2021). Investigating EFL students' perception on online learning amidest COVID-19 pandemic. IJIET, 5(1), 102-115. DOI: 10.24071/ijiet.v5i1.3053

ur Rahman, M. (2020). Challenges and solutions of teaching English as a foreign language online during a global pandemic like COVID-19: Saudi EFL teachers' perspectives. Journal of Southwest Jiaotong University, 55(6), 1-9. DOI : https://doi.org/10.35741/issn.0258-2724.55.6.10

Wheeler, S. (2012). E-Learning and digital learning. In N. M. Seel, Encyclopedia of the Sciences of Learning (pp. 1109-1111). Boston, MA: Springer.

Yulia, H. (2020). Online learning to prevent the spread of Pandemic Corona Virus in Indonesia. Eternal, 11(1), 48-56. DOI:10.26877/eternal.v11i1.6068 